Article

\title{
Conservation Policy-Community Conflicts: A Case Study from Bogda Nature Reserve, China
}

\author{
Qun Liu ${ }^{1,2}$, Zhaoping Yang ${ }^{1, *}$ and Fang Wang ${ }^{3}$ \\ 1 Xinjiang Institute of Ecology and Geography, Chinese Academy of Sciences, Urumqi 830011, China; \\ liuqunnavy@gmail.com \\ 2 University of Chinese Academy of Sciences, Beijing 100049, China \\ 3 Business School, Lishui University, Lishui 323000, China; wangfang@lsu.edu.cn \\ * Correspondence: yangzp@ms.xjb.ac.cn; Tel.: +86-991-788-5472
}

Received: 18 June 2017; Accepted: 21 July 2017; Published: 25 July 2017

\begin{abstract}
Bogda Nature Reserve is a World Heritage Site (WHS) in Xinjiang, China. Potential conflicts between community development and heritage conservation are important topics to study and may have an impact on the sustainable development of heritage sites. In this study, we conducted a survey with the community residents of the Bogda Nature Reserve to examine major potential conflicts arising from local residents' perceptions regarding conservation policy and its interventions. The results indicated that the local community supports heritage conservation and development, but they expressed negative attitudes towards their present living conditions, especially due to policy-induced loss of benefits. Through the research, three major conflicts were identified: (1) a divergence in residents' awareness of the WHS designation and the conservation policy (grazing restriction policy); (2) negative changes in living conditions compared to before the WHS designation; (3) the degradation of well-being caused by tourism. In addition, expectations from residents were combined to assess the implications for the present situation and advise on conservation plans to facilitate sustainable management in Bogda.
\end{abstract}

Keywords: World Heritage Site; residents; policy-community conflicts; Bogda Nature Reserve

\section{Introduction}

The local community is one important stakeholder in World Heritage Sites (WHS), and its participation and support in heritage management are vital to ensure quality of life for community residents as well as to promote sustainable protection and development [1]. Community residents may have lived in a geographical area for generations and comprise a group of people with shared origins or interests [2]. They depend on natural resources, play multiple roles in tourism, and act as guardians of heritage [3]. With tourism development, tourism and recreation have become major occupations in which they participate instead of traditional livelihoods. Accordingly, different interest groups' participation has shaped their various perceptions and assessment of destinations [4], and some issues may potentially lead to tension [5].

The establishment of protected areas, including WHSs, is intended to preserve natural resources and promote management and local service levels [6], while inevitably causing changes and conservation policy-community conflicts for local residents, although the situations vary in different areas. Changes induced by policies can be of different kinds, such as changes in land use patterns, additional requirements for the production of certain goods, or new marketing opportunities for locally produced products [7]. Residents in WHSs mainly experience shifts in livelihood from traditional life to tourism-related activities, restrictions on access to and use of natural resources [8], tourism impacts $[9,10]$, and related limitations that create more complaints [5]. Potential impacts and major issues discerned from community members' perceptions are the key measures to understand 
these situations. Meanwhile, research regarding residents' true feelings behind those changes is still lacking [11]. Thus, there is an urgent need to discover potential tensions and issues perceived by residents regarding conservation policy, which can help planners and managers to make improvements.

Bogda Nature Reserve was successfully designated as a WHS in 2013, and its enhanced international fame has increased the tourism trend there [12], as well as some debates about the heritage reputation. The community in Bogda is mainly composed of Kakazhs, who have been in the area for centuries as herdsmen and cooperate in the protection of natural resources. Since the application for WHS status, conservation policy in Bogda has rapidly evolved with the tourism development of this protected area, especially a grazing restrictions policy that was implemented in 2005. Accordingly, changes in residents' traditional livelihood and the use of natural resources occurred, creating tension between residents and the government. For example, due to the protection regulations, any construction or digging on the land was forbidden, even if individuals had obtained permission. Thus, a survey was conducted in one community located in the buffer zone to analyze major conflicts between community development and heritage conservation, examining the following aspects: (1) residents' awareness of WHS designation and conservation policy; (2) conservation conflicts perceived by the community during heritage development; and (3) possible options for conflict resolution.

\section{Literature Review}

In protected areas, conservation policies are fundamental tools to preserve natural and cultural resources that create both opportunities and restrictions in residents' lives, exerting unintended influence and sometimes resulting in conflict [13]. Though conservation laws have saved some endangered wildlife and natural resources, the use of resources for subsistence-level, basic livelihoods is restricted, a situation that seems to be inconsistent with the interests of local communities [7]. Previous related studies have provided more details on a number of issues, such as policy interventions that induced changes in livelihood [14,15], changes in residents' attitudes towards WHS [1], World Heritage Site designation impacts [12,14], tourism development and its impacts [16-19], and policy conflict issues [13]. Though cases vary in different sites, residents' perceptions are widely used to monitor issues in these studies. It is well known that consulting local communities and understanding their views can achieve public acceptance of protected areas and, ultimately, conservation success [7]. For example, after conducting interviews with partners in the Carpathian Biosphere Reserve, researchers identified specific issues as side effects of the biosphere reserve designation: (1) restrictions in the use of forests; (2) loss of agricultural and pasture land; (3) an increase in wild animals; and (4) protection from floods [7].

The value of WHSs is widely acknowledged as the outstanding universal value, while differences lie in the diverse impacts on residents in specific sites [12]. Some case studies in WHS found that changes in residents' livelihoods are significant, particularly when residents' primary livelihood used to be farming [20], crop/fruit tree/livestock raising [13], forestry [21], agriculture [14], and other traditional activities. Once their traditional livelihoods were replaced by tourism-related activities, more family members became dependent on these activities. Debates over tourism activities and livelihoods led to negative attitudes [17]. Some residents complained about income loss and facing land use change conflicts [22]. A case in Nepal indicated that insufficient compensation schemes to cover the loss from crop and livestock damage and increased restrictions on access to forest resources created conflict between residents and park officials $[23,24]$.

The WHS-embodied cultural and natural values were propitious to tourism development [25]; ecotourism can be a major force in sustainable development of the WHS [26], and also helped to improve local residents' livelihood. Therefore, tourism can effectively promote WHS sustainable development. Meanwhile, some uncontrolled human activities need to be checked in the process of developing ecotourism [10]. In addition, local tourism development also poses major threats to the security of WHSs and exerts both a positive and a negative impact on traditional social and economic conditions $[15,22,27]$. On the positive side, it contributed to well-being, but tourism-induced changes 
on traditional livelihood strategies and lifestyles within the community had a negative influence [13]. On the whole, a positive perception may invite a more favorable attitude towards supporting tourism development [28].

The major challenge facing protected areas is how to develop management systems that balance environmental sustainability and tangible long-term benefits for the local people [5]. Some studies indicated that favorable methods, such as communication mechanisms [2] and income-generating activities [29], are significant ways to promote a good relationship between 'conservation' and 'development'. On the whole, the key problem is to address residents' core interests as central means of sustaining protected areas [29]. Accordingly, community organizations should establish local management organizations [20], including both official institutions and community-based associations. Recently, community-based conservation (CBC) has been well promoted as the most practical approach to stem biodiversity loss [29] and has gained support and development in some regions. In addition, in the Huangshan mountain area, community-based tourism (CBT) is viewed favorably among residents; it not only improved residents' livelihoods and conservation awareness but also built dynamic rule systems to mitigate conflicts [18].

Bogda Nature Reserve was a newly designed site in what used to be the Kazakhs' homeland. Since a complete grazing restriction policy was implemented on nominated properties, the residents' lifestyle was affected in many ways during the heritage development. Therefore, it is important to understand how these residents interpret these major changes in their livelihoods [30], along with their perceptions and their expectations. Moreover, residents' attitudes towards present living conditions in WHS can have significant implications when assessing whether conservation policy, planning, and management are suitable or not.

\section{Study Area and Methods}

This section is organized into two parts. First, we will give a description of the study area, including its geographic features, background development, and reasons for its selection. The second part will provide the methods, including measurement and data collection.

\subsection{Study Area}

The Bogda Nature Reserve is located in Fukang within the Xinjiang Uygur Autonomous Region. The center coordinates are $\mathrm{N} 43^{\circ} 50^{\prime} 00^{\prime \prime} \mathrm{E} 88^{\circ} 17^{\prime} 12^{\prime \prime}$, the nominated property is 38,739 ha, and the buffer zone covers an area of 41,547 ha (Figure 1). Bogda is the highest peak of the north Tianshan Mountains and also includes 12 glacial-dammed lakes; the most famous scenic spot is named Tianchi Lake, approximately $548 \mathrm{~km}^{2}$, with an elevation of $1910 \mathrm{~m}$.

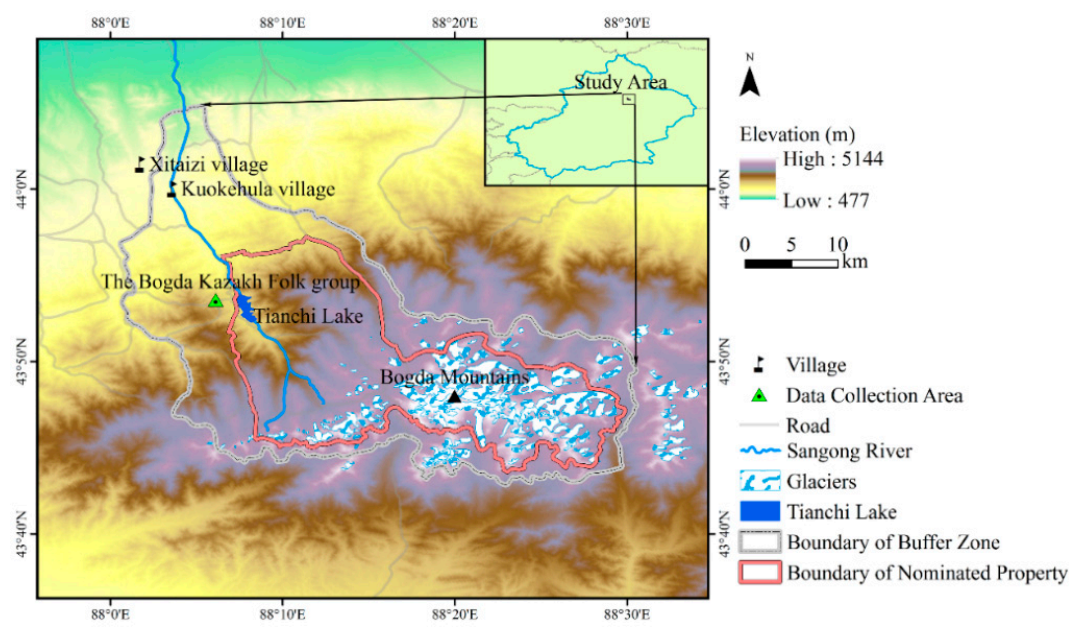

Figure 1. The satellite map for Tianchi Lake in the Bogda Nature Reserve in Xinjiang, China. 
Tianchi Lake has legal protective designations at the national and provincial levels, such as the national 5A-Class scenic, Man and Biosphere Protected Area, National Nature Reserve, National Park, and other titles. Existing plans and related laws and regulations have been put forward as requirements for protection and management, and a multi-level management system was also built. In 2013, the Bogda Nature Reserve was recognized as one part of the World Natural Heritage site at Xinjiang Tianshan (a serial property) in Xinjiang, because Bogda embodies the superlative landscape, exceptional natural beauty, and the most typical representation of vertical mountain zones [31,32]. Furthermore, the declaration text of Xinjiang Tianshan submitted to the World Heritage Centre also offered a scientific and effective planned monitoring system for the protection of Bogda [33]. The enhanced international fame caused an increasing trend in tourism [12], and Tianchi Lake received large numbers of tourists as well as benefits.

Bogda Nature Reserve used to be the homeland to Kakazhs, but it has changed with tourism development. They mainly depended on grazing as herdsmen, and now they participate in tourism activity. The Xinjiang Tianchi Scenic Area Administrative Commission was established in 2006 and charged with tourism management, investment, protection, monitoring, and other workings of the whole scenic spot. From 2003 to 2009, for the application of WHS, stricter protective management was implemented, including a complete grazing restriction on nominated properties; a grazing prohibition in the buffer zone had been in effect since 2005. In 2010, residents were finally resettled according to their livelihood options and given relevant subsistence in different villages. Residents belonging to the Bogda Kazakh Folk group all depended upon the tourist industry with less compensation, but the advantages are that they are next to the core area. Those villages farther away from the core area gained more subsistence, while their livelihoods were farming, raising livestock, and working in local tourist enterprises. The Western Tourism Development Company was entitled to develop tourism activities, such as sightseeing vehicles, shipping, and other commercial activities in Bogda.

The Bogda Kazakh Folk group has been established in the buffer zone, which surrounds the nominated properties, approximately $0.94 \mathrm{~km}$ away from the Tianchi Lake, where a total of 57 households have settled. Residents here are all engaged in tourist accommodation in traditional yurts, numbered in order. The Kazakh ethnic community was established to consult on the local daily affairs in this area. Due to seasonal characteristics, they devoted their time to tourism activities during the period from April to October, then moved to the city of Fukang when winter comes. The Bogda Kazakh Folk group was selected as our study area because grazing is completely banned here and they have been fully dependent upon tourism-related activities for a long time, which helps to provide insight into their attitudes towards those changes based on their rich experience.

\subsection{Measurements and Data Collection}

Our analysis consisted of questionnaires, face-to-face interviews, and a literature review. The pre-survey was conducted during the period of 28-31 July 2015, to verify whether questions were goal-oriented and understandable to residents. After modifications, the second survey was undertaken from 8 to 18 August 2015.

The questionnaire is organized in three main parts: the first part involved the basic information, including gender, age, education, number of family members, and length of residency; the second part investigated the awareness of the WHS designation and conservation policy, questions about notable changes exerted on residents' living conditions, and future expectations; and the last part examined residents' perceptions of tourism impacts. Questions regarding tourism impacts were based on review studies [12,19,34]. A five-point Likert scale was used to capture residents' opinions and attitudes [35], which this study employed to assess tourism impacts. Answers were assessed with scores from 1 to 5 , ranging from 'strongly disagree' to 'strongly agree'. Higher scores mean stronger agreement. These data were finally processed with a statistical program, SPSS 17.0 (SPSS Inc., Chicago, IL, USA).

There was a total sample of 57 households in this community village. Each interview lasted between 20 and $40 \mathrm{~min}$, and a representative member from each family was also encouraged to share 
personal and honest views to discuss controversial issues during the survey. Most Kazakh residents were willing to be involved in this survey. When faced with refusal, we thanked the residents and left. Some participants lacked comprehensive understanding of the questions [14]; however, one local university student volunteered to assist us with translation to smoothly promote our survey. Some respondents finished it by themselves. A total of 52 households were investigated, from which 48 questionnaires were valid, and the effective rate was $92 \%$.

In addition to the investigations of residents, some members from the Tianchi Scenic Area Administrative Commission and Western Tourism Development Company were also invited to talk separately about some key issues. Comparing answers from different views allows for fair judgement of the various problems. During the investigation, some tourists also gave constructive suggestions.

\section{Results}

\subsection{Profiles of Respondents}

This investigation covers approximately $84 \%$ of the respondents: $62.5 \%$ are male, and $37.5 \%$ are female. The majority (62.5\%) were aged between 36 and 50. With the development of this area, a considerable part (39.6\%) had obtained a high-school degree, and approximately $10.4 \%$ had earned a college degree or higher. Most Kazakh families (62.5\%) consisted of four or five members. The Kazakh ethnic group has developed in this area over generations, and over half of the respondents had been here for more than 11 years, with $35.4 \%$ of them reporting they had lived in the area more than 21 years, and only a small percentage of respondents $(16.7 \%)$ reporting that they had moved here within the past five years (Table 1).

Table 1. Profiles of respondents.

\begin{tabular}{ll}
\hline Demographic Characteristics $(\boldsymbol{n}=\mathbf{4 8})$ & Percentage (\%) \\
\hline Gender & 62.5 \\
Male & 37.5 \\
Female & \\
\hline Age & 14.6 \\
35 and under & 62.5 \\
$36-50$ & 22.9 \\
51 and above & \\
\hline Education & 18.8 \\
Under primary school degree & 31.2 \\
Middle School degree & 39.6 \\
High School degree & 10.4 \\
College degree or above & \\
\hline Number of family members & 27.1 \\
Below 3 & 62.5 \\
4-5 & 10.4 \\
Over 6 & \\
\hline Length of Residency & 16.7 \\
Below 5 years & 27.1 \\
6-10 years & 35.4 \\
11-20 years & 20.8 \\
Over 21years & \\
\hline
\end{tabular}

\subsection{Divergence in Awareness}

\subsubsection{Awareness of WHS Designation}

The question about awareness of WHS designation is asked to verify residents' understanding of the site. Local residents participated in the nomination process to varying degrees, so their awareness 
about WHS is probably related to the roles they played in this process. The majority ( $85.4 \%)$ clearly know that the Bogda Nature Reserve has been a WHS and are proud of their homeland; only $14.6 \%$ do not know the WHS' relevance to the Bogda Nature Reserve, and the meaning of the term 'World Natural Heritage Site' is strange to some residents, though after a brief explanation about its origins and process they came to recognize it (Figure 2).

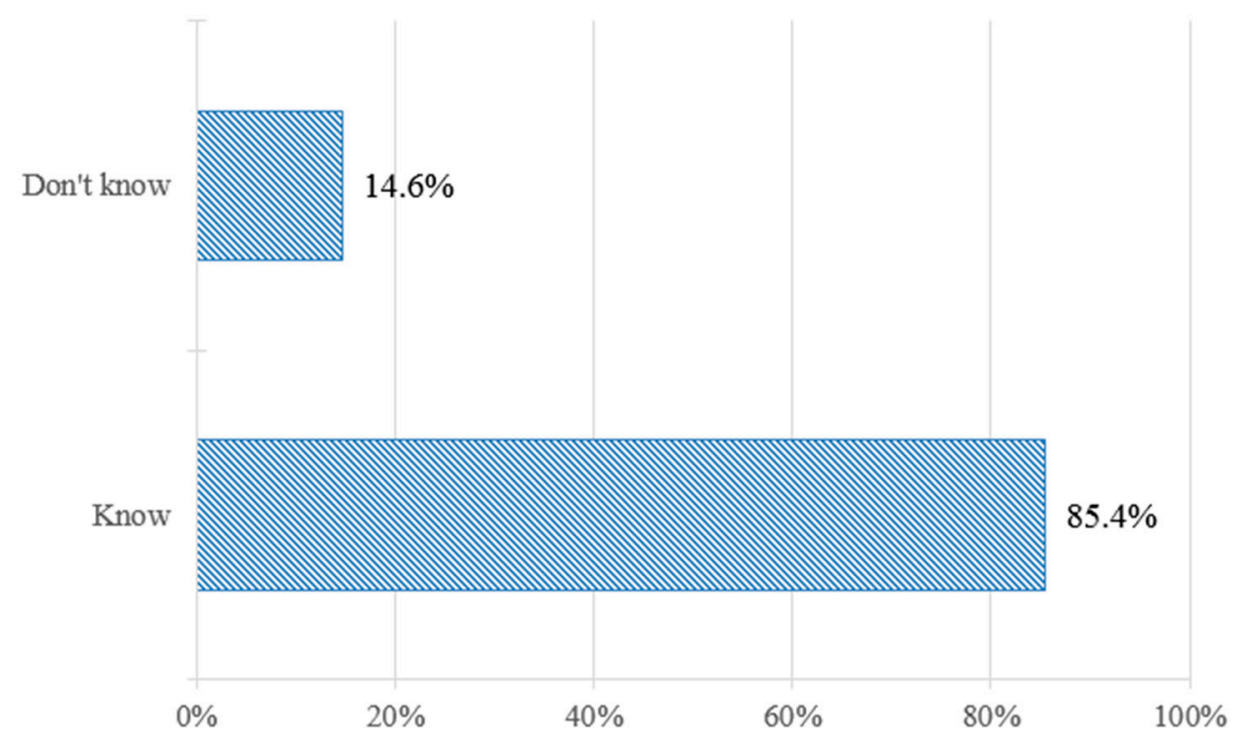

Figure 2. Awareness of Bogda Nature Reserve's status as a WHS.

Surprisingly, respondents have always attached the Bogda heritage site to the policy-grazing restriction, regarding the site's designation as a policy enhancement instead of a matter of fame. It is noteworthy that residents do not distinguish clearly between the WHS designation and policy, and thus some respondents believe that the WHS's purpose is to create policy as a government tool. This is probably due to the application for WHS status, a process that affected respondents and in which they gradually participated. Their perceptions of the WHS mainly presented in the following aspects, while further explorations showed that major changes caused by the WHS designation were derived from residents' various perceptions: most respondents perceived the designation as a grazing restriction policy $(35.4 \%)$; the increased tourism influence $(29.2 \%)$, which became their main income source, was the next most common view. Their traditional livelihood $(6.2 \%)$ had been replaced, their life was filled with new regulations to obey (10.4\%), and ecological migration activity $(18.8 \%)$ also played an important role in this change (Table 2).

Table 2. Major changes perceived by residents.

\begin{tabular}{cc}
\hline Perceived Major Changes Caused by WHS Designation & Percent (\%) \\
\hline Grazing restriction policy & 35.4 \\
More legal regulations & 10.4 \\
Livelihood changes & 6.2 \\
Tourism influence & 29.2 \\
Ecological migration activity & 18.8 \\
\hline
\end{tabular}

\subsubsection{Awareness of Conservation Policy}

Conservation policy is implemented to preserve the environment with regulations, and the grazing restriction policy was the dominant one in Bogda. Most respondents knew the reasons for the grazing restriction implementation, while attitudes towards this policy seemed to not be in accordance 
with the official statements. The majority of respondents (64.6\%) claimed that grazing activity had never affected the grassland ecosystem because they clearly knew how to graze sustainably with traditional skills. Approximately $25.0 \%$ of respondents admitted that grazing had only a slight effect in special areas, and the policy is only helpful to control excessive grazing. Only $10.4 \%$ of respondents stated that grazing was balanced in dynamics (Figure 3), for grazing intensity can be coordinated with environmental capacity in a dynamic balance in WHS. Due to the long-term impacts of this policy, residents with intimate knowledge of traditional herding methods also expressed serious worries about the potential threats of a lifestyle without grazing.

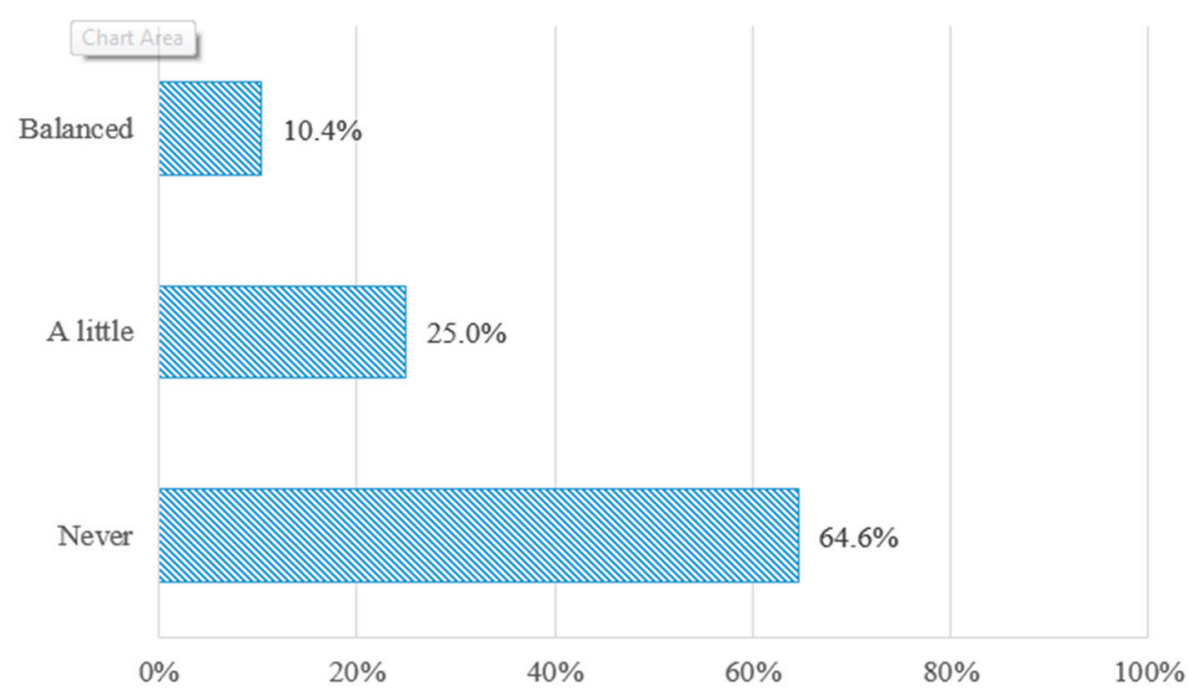

Figure 3. Perceptions of grazing effects with respect to the WHS. The term 'balanced' means that grazing intensity can be coordinated with environmental capacity in a dynamic balance in WHS. 'A little' means that residents admitted that grazing had a minor negative effect on the ecological system in WHS. 'Never' means that residents believed that the WHS status had no effect on grazing because residents are confident in their traditional grazing skills.

\subsection{Conflicts in Conservation Policy}

\subsubsection{Comparative Changes in Living Conditions}

To verify why they regarded the WHS as a grazing restriction policy and thus resented it, major perceptions were analyzed by comparing some aspects of living conditions before the WHS designation and after the WHS designation, along with the policy implementation. Conflicts with the WHS designation directly referred to the grazing restriction policy, which caused restrictions, shifts, and economic losses in lifestyle, presented in three aspects: livelihood activities, the number of members involved in tourism, and the annual income variety.

According to respondents' descriptions, before the WHS designation, their primary activity was grazing, with only small, part-time activities in tourism. After the WHS designation, grazing was banned, and the remaining choices were variously related to tourism, such as tour operators, drivers, and workers in a tourism enterprise, as well as forest guards concerned with protection.

Results in Figure 4 indicated that before the WHS designation, only 1-2 members had participated in tourism, accounting for $52.1 \%$ of households, while after the WHS designation an increased proportion of $85.4 \%$ (more than three members) had engaged in tourism. As tourism became the primary livelihood, participation was ultimately enhanced.

Annual income variation was a sensitive problem in respondents' daily life; therefore, it spurred the question "What was your annual income before and after the WHS designation?" Significant income variation was estimated based on their answers (Figure 5). Before the WHS designation, 
almost 22 (45.8\%) of the respondents earned more than 80,001 Yuan RMB each year, and only three (6.2\%) earned less than 20,000 Yuan RMB each year. However, since the grazing restriction policy was implemented, the situation has been reversed; the majority of 19 (54.2\%) of respondents experienced relatively poor conditions, making below 40,000 Yuan RMB on average, while only seven $(14.6 \%)$ respondents attained annual incomes above 80,001 Yuan RMB, showing a significant shift from above 80,001 Yuan RMB to the range of 20,001-40,000 Yuan RMB.

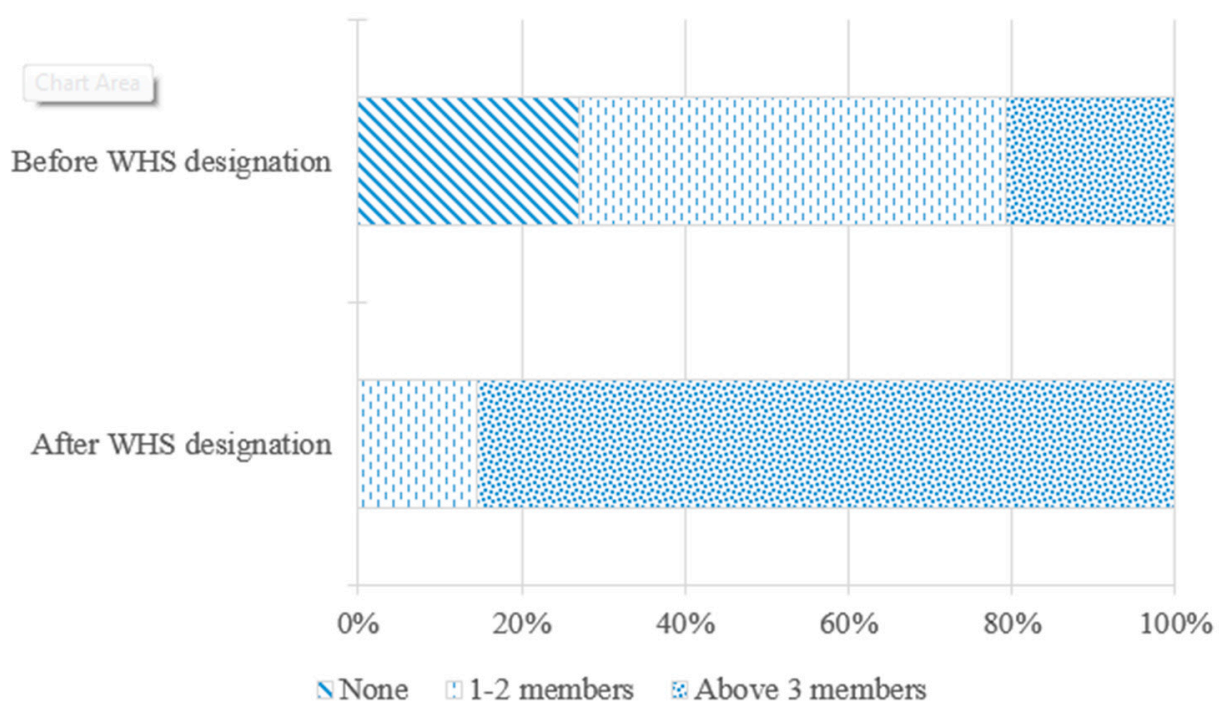

Figure 4. The number of residents engaged in tourism before and after WHS designation.

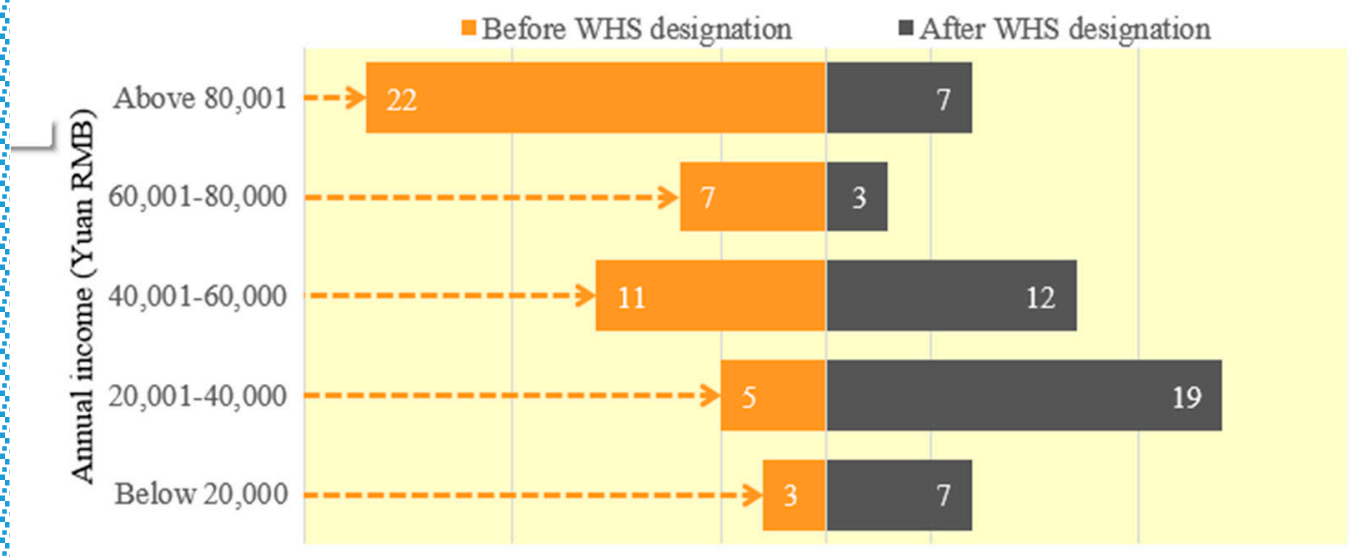

Figure 5. Average annual income before and after WHS designation.

One elderly grandfather said, with his grandson's translation, "I quite disagree with these policies. Our children suffer more labor all day long, while the old people just sit there and can do nothing. Little children need education, family needs to be supported, living environment needs preservation, everyone was pushed to work on, and traditional life seemed to have gone. We are suffering such heavy pressure".

\subsubsection{Perceptions of Tourism-Induced Impacts}

Tourism development is one factor that creates changes to improve or threaten the quality of life [36]. This score is calculated as an average from a five-point scale $(1=$ strongly disagree, $5=$ strongly 
agree); overall, respondents gave mean scores to these three main impacts items that ranged from 2.35 to 4.50 (Table 3).

Economically, respondents gave an overall mean score of 3.19 and the mean percentage of agreement is $50 \%$, which is relatively negative. The score for enhancing commercial awareness $(\mathrm{M}=4.00,83.33 \%)$ was the highest, followed by the score for comfortable standard of living $(\mathrm{M}=3.31$, $54.17 \%)$. Some believed that tourism had created more jobs and opportunities ( $\mathrm{M}=3.10,41.67 \%)$, while $29.17 \%$ of the respondents were neutral. Economic loss was obvious, with only $20.83 \%$ believing that they had gained benefits; this item received the lowest mean score, of 2.35. One young, wealthy and educated man stated, "As Kazakhs, we used to inherit nice traditions to treat guests warmly with our best food and a meal of lamb without payment, a payment of some sugar cubes was fine, because we believed that it was a shame to ask for money. Now, we are changed, everything needs money, sometimes we are even confronted with paying fines for conservation. The more money we gain, the more modernized life will be, while free life with dancing and grazing is passing away ... ".

Table 3. Assessments of tourism-induced impacts.

\begin{tabular}{lccc}
\hline \multicolumn{1}{c}{ Impact Variables } & Mean & SD & Agree (\%) \\
\hline Perceptions on economic impacts & & & \\
$\quad$ Tourism increased our economic benefits & 2.35 & 1.10 & 20.83 \\
$\quad$ Tourism created more jobs & 3.10 & 1.19 & 41.67 \\
$\quad$ Tourism improved the standard of living & 3.31 & 1.37 & 54.17 \\
$\quad$ Tourism enhanced our commercial awareness & 4.00 & 0.97 & 83.33 \\
\hline Perceptions on environmental impacts & & & \\
$\quad$ Our community infrastructure has been improved & 4.35 & 0.98 & 58.33 \\
$\quad$ Environmental protection awareness has been enhanced & 4.31 & 0.95 & 81.30 \\
$\quad$ Living environment in WHS has been well preserved & 2.50 & 1.19 & 22.92 \\
\hline Perceptions of socio-cultural impacts & & & \\
$\quad$ We started to preserve cultural identity & 3.46 & 1.41 & 58.33 \\
$\quad$ We gained more cultural exchange & 4.50 & 0.83 & 64.58 \\
We achieved great improvement in knowledge & 4.17 & 1.16 & 79.17 \\
\hline Support for tourism development in WHS & & & \\
$\quad$ We will assist tourism plans and development & 4.13 & 0.87 & 81.25 \\
$\quad$ We will obey environmental principles & 3.50 & 1.27 & 64.58 \\
$\quad$ We are so proud of WHS & 4.40 & 0.68 & 93.70 \\
\hline
\end{tabular}

Note: SD, Standard deviation. Agree (\%) means the total percentage of agreement.

Environmentally, respondents gave an overall mean score of 3.72, and the mean percentage of agreement is $54.18 \%$. Most respondents agreed that their awareness of environmental protection had improved $(\mathrm{M}=4.31,81.30 \%)$ and that basic infrastructure made social services more convenient ( $\mathrm{M}=4.35,58.33 \%)$, but neutral opinion was expressed by approximately $27.08 \%$ of people, who argued that there were unfair limitations on their personal life. The lowest mean score was given to "Living environment in WHS is preserved" $(\mathrm{M}=2.50,22.92 \%)$. In terms of the total environmental conditions, older respondents mentioned a deficiency in monitoring grassland health since the grazing restrictions.

Socio-culturally, respondents gave an overall mean score of 4.04, and the mean percentage of agreement is $67.36 \%$, which is relatively positive. Since participating in the tourism activity, all aspects of Kazakhs' daily life, including customs, language, and living skills, have been affected by modern life. The traditional culture exchange gained the highest score $(\mathrm{M}=4.50,64.58 \%)$; respondents were proud to introduce their culture to tourists, while the neutral opinion for this element was $25.00 \%$. Knowledge improvement received a higher score $(\mathrm{M}=4.17,79.17 \%)$. Though they formally displayed exhibitions to tourists, they still insisted that their traditional culture was missing in modern life, and thus their cultural identity evaluation was weaker $(\mathrm{M}=3.46,58.33 \%)$. 
Regarding attitudes towards tourism development in WHS, despite the negative impacts exerted on their life, respondents gave higher scores with a mean value of 4.01 , and $79.84 \%$ of them showed favorable attitudes. They were proud of their community $(\mathrm{M}=4.40,93.70 \%)$, and respondents showed positive attitudes towards assisting tourism plans and development $(\mathrm{M}=4.13,81.25 \%)$ in following environmental principles $(\mathrm{M}=3.50,64.58 \%)$.

\subsection{Future Expectations}

In addition to the detected conflicts, residents' expectations were also investigated. When given alternate choices of occupation, the majority $(52.1 \%)$ of respondents hoped to engage in grazing along with tourism. Approximately $20.8 \%$ of the respondents still insisted that the tourism activities were better, while only $18.8 \%$ chose to only graze; other occupation choices represented $8.3 \%$ of respondents (Figure 6). Open interviews with respondents revealed a strong willingness to gain more benefits and a freer life, a preference for increased subsidies from the government, and a view that life was better overall. However, some respondents were eager to return to their original life, calling for a traditional lifestyle with grazing and manifesting an urgent desire to obtain more favorable policies and more job opportunities in their present life.

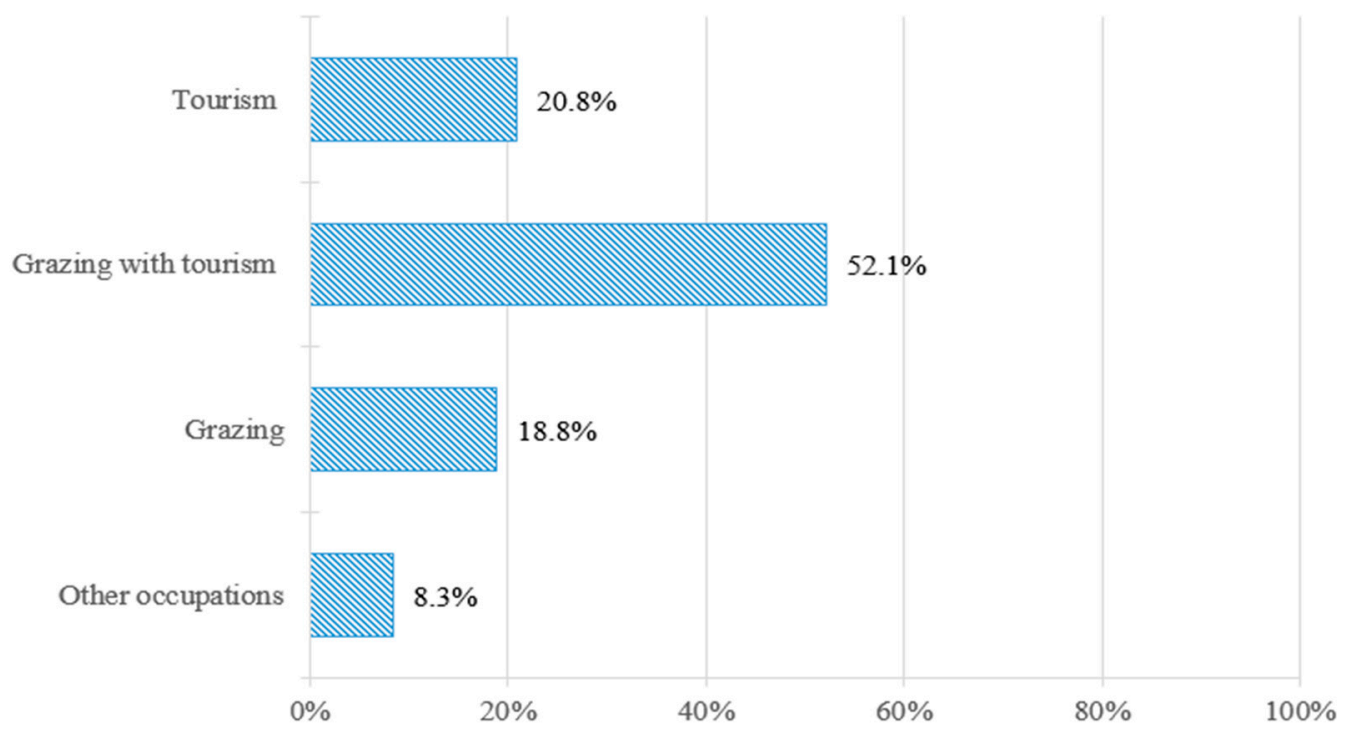

Figure 6. Respondents' expected occupations in Bogda Nature Reserve.

During the interviews, local managers decried the great pressures on management and investments, a deficiency of professional people, weak monitoring, and views that full protection cannot be fulfilled in such a limited time and requires gradual improvement instead. At present, ecological recovery, rubbish collection, and building management are still key problems to be solved. The private representatives also showed great passion to contribute to tourism development. Moreover, some tourists also suggested keeping sheep around the yurts, which is an important part of the Kazakh landscape and could also present the scenery for tourists' curiosity and expectations.

\section{Discussion}

Since the Bogda Nature Reserve was designated as a WHS, its reputation has attracted an increasing number of tourists. Residents appreciated their conserved natural resources, better services, and economic benefits, and they were positively involved in tourism development. However, due to the impact of the conservation policy, their attitudes were negative towards benefit losses in different aspects, even though they still support local heritage conservation. In this study, three major conflicts 
were detected: (1) divergence in residents' awareness of the WHS designation and the conservation policy; (2) significant changes emerging in the comparisons of the period before and after the WHS designation; and (3) degradation of well-being in life caused by tourism impacts.

\subsection{Divergence in Awareness}

The results highlighted that residents perceived the WHS designation to be an enhanced version of a grazing restriction policy instead of a marker of reputation. Residents understood the designation of WHS and recognized the conservation policy was aimed at WHS protection, while they tended to associate WHS with its policy and were sensitive to the policy's impacts and its threats to livelihoods.

The misunderstanding of these two terms may be partially affected by the impact of conservation policy; the reasons for this assumption were derived both from individual thoughts and external influence. The internal cause was that residents disagreed with local announcements regarding the policy's objectives. Due to policy regulations, residents are excluded from protected areas [36] and deprived of their traditional livelihood. They believed that the grazing restriction was unreasonable, and that grazing's impact on nature conservation can be better addressed in traditional ways. Furthermore, residents with intimate knowledge of traditional herding methods stated that the grassland ecosystem even indicated unhealthy status under long-term limitations. The external cause was that they complained of unfair treatment under conservation policy, which seemed to place limitations only on residents, while other stakeholders were excluded, a situation opposite to previous promises. This phenomenon also appeared in Royal Bardia National Park because non-governmental organizations enjoyed preferential treatment from management while residents did not [37].

Residents' awareness varies regarding heritage developments and is affected by conservation programs in the WHS, and these various impacts may shape different individuals' perspectives [38]. Furthermore, residents' awareness had a significant effect on their involvement in the development process [28]. Broad-based education and awareness campaigns can increase understanding and support for local development [16]. Therefore, local organizations should take initiatives to help residents clearly recognize the distinction between the perceived meaning and the official statement with respect to the terms of the WHS and conservation policy. The media are encouraged to train and educate local communities to improve their awareness, knowledge, and readiness for heritage conservation programs and participation in tourism development process [19], as well as to create effective negotiation and conflict management strategies for conservation policy issues [39]. The earlier people recognize the meaning of WHS and its implications, the better the perceptions that will be formed.

\subsection{Comparisons in Living Conditions}

By comparing living conditions before and after the WHS designation, the results indicated that significant changes were directly related to policy-induced negative impacts. The policy-induced benefits loss appeared to be the source of conflict, which was consistent with previous studies [39]. Significant changes were mainly presented in three aspects: the variation of livelihood activities, the growing number of members involved in tourism, and reduced annual income. A similar phenomenon also occurred in other protected areas [40].

In Bogda, since the conservation policy was implemented, traditional activities were restricted and residents shifted from nomadism to tourism-related industry, suffering both benefits and economic loss. Considering that more members now participate in tourism activities, high dependence on tourism as the single livelihood option may reduce sustainability [21], because tourism is an unstable and risky industry compared to traditional industries, and its highly seasonal nature and external factors are usually beyond human control. Meanwhile, developing ecotourism is also helpful to improve the livelihoods of local residents in the WHS [10]. Additionally, residents also argued that the other competitors involved in tourist reception nearby also threatened their economic benefits, making pressures heavier. 
The pursuit of their original lifestyle and avoidance of present life has created dissatisfaction [29]. People blamed benefits loss on the conservation policy, and comparisons of the past and present reveal that rural poverty exacerbated the need for an open policy of grazing and natural resource use in WHS public areas, which are instead slapped with prohibitions. Thus, it is suggested that the government address local development needs for long-term biodiversity conservation goals and encourage improved management in the area [2].

\subsection{Conflicts about Tourism Impacts}

Tourism is one of the core income-generating activities for many heritage sites and can fund heritage conservation [2]; while the situation depends on various factors, tourism might also disrupt livelihood systems, social processes, and cultural traditions [21]. Residents' views in the Bogda area suggest that tourism has brought more benefits and positive improvements, but negative impacts were still significant.

Economically, respondents indicated that tourism has created more employment opportunities, their commercial awareness was enhanced, and they have gained a better living standard, while the lowest scores given to economic benefits revealed that some residents perceived their lives as worse than before. Regarding conservation goals in WHS, local residents have been deprived of their traditional livelihood and policy has directly affected the local people's lifestyle [2]; residents attributed their economic loss to the policy's influence. Therefore, governments need to help residents increase the benefits derived from heritage development.

Environmentally, residents were aware that local environment conservation had been promoted and basic infrastructure made social services more convenient, but they perceived that conservation management seemed to go against the proposed goal. Despite the impacts from tourist activities, residents tended to attribute the damaged environment to the managers, while welcoming more tourists for added benefits [38]. Importantly, residents frequently mentioned the issue that fires may occur in the grassland, which matches a similar worry in Bianchi's study [21]; many residents asserted that the increased incidence of forest fires was the result of livestock having been removed from the forest. The government workers in Bogda also showed concern that residents' worries about the environmental conservation were also their responsibility. However, they faced challenges that meant that, although they realized residents' concern, they had no right to implement widely expanded access. Therefore, communication should be open and shared with more groups when discussing development issues in this heritage site, to clarify each view and promote wider collaboration.

Socio-culturally, culture exchange and cultural identity were enhanced [8], and residents welcomed knowledge improvement, while some observed their traditions as threatened in a way. Since residents engaged in tourism, the community had established a stable life at home, gained more cultural exchange with tourists, and been educated by the wider world [41]. In addition to an outstanding heritage resource, traditional culture in World Heritage Sites is also a major tourism attraction, appealing to most visitors [8]. In Bogda, residents were concerned that their traditional Kazakh customs have been affected by modernization, including language, traditional customs, inheritance, and other precious traditions. Therefore, for the intangible elements present in a WHS, local governments, private enterprises, and tourists should help residents carry on their cultural heritage protection for future generations.

In terms of attitudes towards heritage conservation and development, all residents in Bogda, more or less, showed great support for the local tourism development despite the negative impacts, and they were eager to be involved in tourism activities following environmental principles and tourism plans, as well as to guard their hometown. Similar studies in Makalu-Barun National Park [40] indicated that, although people in Makalu-Barun National Park did not appreciate the policy due to the loss of economic benefits, they still supported the protection. The support in Bogda probably derives from different motivations, but further economic benefits and a better life are the key motivations [5]. 


\subsection{Future Expectations}

Benefits are an incentive for people to perceive conservation positively [42]. Open interviews with respondents revealed that there was a strong willingness to gain more benefits with a freer life, a preference for increased subsidies from the government, and a view that 'the more the better.' In response to the choice of a new life, more than half of the respondents preferred an occupation blending grazing with tourism activity, combining traditional and modern lifestyles.

The economic loss in Bogda reminded residents of their original lives, forming a negative avoidance reaction to modern life. The rich respondents seemed to pursue a traditional life, while the poor preferred higher benefits. Some respondents were eager to obtain more favorable policies and more job opportunities in their present life. Examples in the Nanda Devi Biosphere Reserve indicated that residents viewed a realized income from timber from dead, diseased trees in community forests and medicinal plants for tourism as potential development options [17]. Residents in Bogda desired increased compensation from the government, consistent with the case in the Huangshan mountain area [20]. However, although compensation can probably improve the situation quickly, it is not a wise strategy for sustainable development. Further success requires more cooperation, involvement, and a balance between the demands of modern society and respect for traditional cultures; with these, the longer-term pursuit of value can be sustainable [8].

\section{Conclusions}

Based on these obvious issues, residents held complex attitudes towards conservation policy and heritage development; they appreciated the benefits of the WHS reputation and tourism activity and support its conservation, but they did not view the policy-induced benefit loss and restrictions favorably. For long-term sustainability to be assured, potential methods were suggested that provide important implications for heritage development and policy-makers.

First, understanding the local community's perceptions is the starting point from which to identify issues because awareness, sound management structure, and effective management capabilities can help residents develop better relationships with local activities.

Second, ensuring economic benefits and resolving concerned issues require the involvement of more stakeholders. It is also better to use open communication mechanisms with clear direction on the policy issues and potential concerns in order to let residents' voices be heard, as well as those of local stakeholders and experts. For the intangible elements concerned in WHS, more stakeholders should help residents to carry on their cultural heritage protection. We suggested that women make souvenirs to sustain culture and obtain economic benefits.

Third, to promote sustainable harmonious development, the government should fulfill the promises it made to its residents. Another issue that should be considered is that sustainable development should be accompanied by continued assessment and dynamic monitoring. Present policies in the Bogda Nature Reserve should be reassessed by experts to give sustainable suggestions. Perhaps moderate grazing will be a way to contribute to environmental conservation, enrich economic benefits, and sustain residents' traditional lifestyle.

Acknowledgments: The research was supported by the Science and Technology Service Network Initiative of Chinese Academy of Sciences (KFJ-SW-STS-181), the National Key Technology R\&D Program of China (2016YFC0503306), and the Western PHD project of Chinese Academy of Sciences (2015-XBQN-B-19). Special thanks are owed to the editors and anonymous reviewers who gave constructive suggestions and comments for improving this article. We sincerely thank all the respondents involved in this survey.

Author Contributions: All authors contributed to designing the research and the questionnaire, as well as writing and revising the manuscript. Qun Liu and Fang Wang carried out the survey. All authors participated in analyzing the data and wrote the paper.

Conflicts of Interest: The authors declare no conflicts of interest. 


\section{References}

1. Nicholas, L.N.; Thapa, B.; Ko, Y.J. Residents' perspectives of a world heritage site: The pitons management area, St. Lucia. Ann. Tour. Res. 2009, 36, 390-412. [CrossRef]

2. Aas, C.; Ladkin, A.; Fletcher, J. Stakeholder collaboration and heritage management. Ann. Tour. Res. 2005, 32, 28-48. [CrossRef]

3. Nyaupane, G.P.; Timothy, D.J. Heritage awareness and appreciation among community residents: Perspectives from Arizona, USA. Int. J. Herit. Stud. 2010, 16, 225-239. [CrossRef]

4. Tosun, C. Expected nature of community participation in tourism development. Tour. Manag. 2006, 27, 493-504. [CrossRef]

5. Tomićević, J.; Shannon, M.A.; Milovanović, M. Socio-economic impacts on the attitudes towards conservation of natural resources: Case study from Serbia. For. Policy Econ. 2010, 12, 157-162. [CrossRef]

6. Poria, Y.; Reichel, A.; Cohen, R. Tourists perceptions of world heritage site and its designation. Tour. Manag. 2013, 35, 272-274. [CrossRef]

7. Wallner, A.; Bauer, N.; Hunziker, M. Perceptions and evaluations of biosphere reserves by local residents in Switzerland and Ukraine. Landsc. Urban Plan. 2007, 83, 104-114. [CrossRef]

8. Okech, R.N. Socio-cultural impacts of tourism on world heritage sites: Communities' perspective of lamu (Kenya) and Zanzibar Islands. Asia Pac. J. Tour. Res. 2010, 15, 339-351. [CrossRef]

9. Almeida-García, F.; Peláez-Fernández, M.Á.; Balbuena-Vázquez, A.; Cortés-Macias, R. Residents' perceptions of tourism development in Benalmádena (Spain). Tour. Manag. 2016, 54, 259-274. [CrossRef]

10. Bego, F.; Malltezi, J. Ecotourism Opportunities and Challenges in Butrint, Albania, a Unique UNESCO and Ramsar site. J. Coast Res. 2011, 61, 150-157. [CrossRef]

11. Wall, G.; Black, H. Global heritage and local problems: Some examples from Indonesia. Curr. Issues Tour. 2004, 7, 436-439. [CrossRef]

12. Kim, S. World heritage site designation impacts on a historic village: A case study on residents' perceptions of Hahoe village (Korea). Sustainability 2016, 8, 258. [CrossRef]

13. Maikhuri, R.K.; Nautiyal, S.; Rao, K.S.; Saxena, K.G. Conservation policy-people conflicts: A case study from nanda devi biosphere reserve (a world heritage site), India. For. Policy Econ. 2001, 2, 355-365. [CrossRef]

14. Jimura, T. The impact of world heritage site designation on local communities-A case study of Ogimachi, Shirakawa-mura, Japan. Tour. Manag. 2011, 32, 288-296. [CrossRef]

15. Mbaiwa, J.E. Changes on traditional livelihood activities and lifestyles caused by tourism development in the Okavango Delta, Botswana. Tour. Manag. 2011, 32, 1050-1060. [CrossRef]

16. Andereck, K.L.; Valentine, K.M.; Knopf, R.C.; Vogt, C.A. Residents' perceptions of community tourism impacts. Ann. Tour. Res. 2005, 32, 1056-1076. [CrossRef]

17. Mbaiwa, J.E.; Stronza, A.L. Changes in resident attitudes towards tourism development and conservation in the Okavango Delta, Botswana. J. Environ. Manag. 2011, 92, 1950-1959. [CrossRef] [PubMed]

18. Qian, C.; Sasaki, N.; Shivakoti, G.; Zhang, Y. Effective governance in tourism development-An analysis of local perception in the Huangshan Mountain area. Tour. Manag. Perspect. 2016, 20, 112-123. [CrossRef]

19. Rasoolimanesh, S.M.; Jaafar, M.; Ahmad, A.G.; Barghi, R. Community participation in world heritage site conservation and tourism development. Tour. Manag. 2017, 58, 142-153. [CrossRef]

20. Bianchi, R.V. The contested landscapes of world heritage on a tourist island: The case of Garajonay National Park, La Gomera. Int. J. Herit. Stud. 2002, 8, 81-97. [CrossRef]

21. Su, M.M.; Wall, G.; Xu, K. Tourism-induced livelihood changes at mount Sanqingshan world heritage site, China. Environ. Manag. 2016, 57, 1024-1040. [CrossRef] [PubMed]

22. Sirima, A.; Backman, K.F. Communities' displacement from national park and tourism development in the Usangu Plains, Tanzania. Curr. Issues Tour. 2013, 16, 719-735. [CrossRef]

23. Buckley, R. The effects of world heritage listing on tourism to australian national parks. J. Sustain. Tour. 2004, 12, 70-84. [CrossRef]

24. Karanth, K.; Nepal, S. Local residents perception of benefits and losses from protected areas in India and Nepal. Environ. Manag. 2012, 49, 372-386. [CrossRef] [PubMed]

25. Su, M.; Geoffrey, W. Community Participation in Tourism at a World Heritage Site: Mutianyu Great Wall, Beijing, China. Int. J. Tour. Res. 2014, 16, 146-156. [CrossRef] 
26. Tikhonov, V.; Koen, W. Poverty Alleviation through Ecotourism in the Three Parallel Rivers World Heritage Site, Yunnan China. Master's Thesis, University of Oslo, Oslo, Norway, 24 May 2011.

27. Li, M.; Wu, B.; Cai, L. Tourism development of world heritage sites in China: A geographic perspective. Tour. Manag. 2008, 29, 308-319. [CrossRef]

28. Rasoolimanesh, S.M.; Jaafar, M. Sustainable tourism development and residents' perceptions in world heritage site destinations. Asia Pac. J. Tour. Res. 2016, 1-15. [CrossRef]

29. Mehta, J.N.; Kellert, S.R. Local attitudes toward community-based conservation policy and programmes in Nepal: A case study in the Makalu-Barun conservation area. Environ. Conserv. 1998, 25, 320-333. [CrossRef]

30. Han, F.; Yang, Z.; Shi, H.; Liu, Q.; Wall, G. How to promote sustainable relationships between heritage conservation and community, based on a survey. Sustainability 2016, 8, 886. [CrossRef]

31. Wu, C.; Wu, G.; Shen, J.; Dai, X.; Chen, J.; Song, H. Late quaternary tectonic activity and crustal shortening rate of the Bogda Mountain area, eastern Tianshan, China. J. Asian Earth Sci. 2016, 119, 20-29. [CrossRef]

32. Xu, X.; Yang, Z.; Saiken, A.; Rui, S.; Liu, X. Natural heritage value of Xinjiang Tianshan and global comparative analysis. J. Mt. Sci. 2012, 9, 262-273. [CrossRef]

33. Wang, Z.; Du, X. Monitoring natural world heritage sites: Optimization of the monitoring system in Bogda with gis-based multi-criteria decision analysis. Environ. Monit. Assess. 2016, 188, 1-17. [CrossRef] [PubMed]

34. Almeida García, F.; Balbuena Vázquez, A.; Cortés Macías, R. Resident's attitudes towards the impacts of tourism. Tour. Manag. Perspect. 2015, 13, 33-40. [CrossRef]

35. Bujosa Bestard, A.; Nadal, J.R. Modelling environmental attitudes toward tourism. Tour. Manag. 2007, 28, 688-695. [CrossRef]

36. Redpath, S.M.; Young, J.; Evely, A.; Adams, W.M.; Sutherland, W.J.; Whitehouse, A.; Amar, A.; Lambert, R.A.; Linnell, J.D.C.; Watt, A.; et al. Understanding and managing conservation conflicts. Trends Ecol. Evol. 2013, 28, 100-109. [CrossRef] [PubMed]

37. Allendorf, T.D.; Smith, J.L.D.; Anderson, D.H. Residents' perceptions of Royal Bardia National Park, Nepal. Landsc. Urban Plan. 2007, 82, 33-40. [CrossRef]

38. Rivera, M.; Croes, R.; Lee, S.H. Tourism development and happiness: A residents' perspective. J. Destin. Mark. Manag. 2016, 5, 5-15. [CrossRef]

39. Fearnside, P.M. Conservation policy in Brazilian Amazonia: Understanding the dilemmas. World Dev. 2003, 31, 757-779. [CrossRef]

40. Brockington, D. Community conservation, inequality and injustice: Myths of power in protected area management. Conserv. Soc. 2004, 2, 411-432.

41. Besculides, A.; Lee, M.E.; McCormick, P.J. Residents' perceptions of the cultural benefits of tourism. Ann. Tour. Res. 2002, 29, 303-319. [CrossRef]

42. Mutanga, C.N.; Vengesayi, S.; Muboko, N.; Gandiwa, E. Towards harmonious conservation relationships: A framework for understanding protected area staff-local community relationships in developing countries. J. Nat. Conserv. 2015, 25, 8-16. [CrossRef]

(C) 2017 by the authors. Licensee MDPI, Basel, Switzerland. This article is an open access article distributed under the terms and conditions of the Creative Commons Attribution (CC BY) license (http://creativecommons.org/licenses/by/4.0/). 